\title{
The first generation college student experience: A case study
}

\author{
Margaret Costello * \\ School of Nursing and Health Sciences, Simmons College, Boston, United States
}

Received: July 18, 2016

DOI: $10.5430 /$ jnep.v7n1p62

\author{
Accepted: August 5, 2016 \\ Online Published: August 24, 2016 \\ URL: http://dx.doi.org/10.5430/jnep.v7n1p62
}

\begin{abstract}
Background: For first-generation college students-the first in their families to seek postsecondary education-the college experience can be an especially isolating and stressful time. The high-stakes nursing environment may exacerbate the stress experienced by these nursing students.

Methods: This article describes the case of a first generation nursing student who personifies the issues many students (FGS) first-generation college encounter in nursing education. The current literature related to barriers faced by FGS is reviewed. The literature was searched in nursing and educational databases (CINAHL, ERIC) for 2011-2016. Keywords used in the search included first generation college students, first generation nursing students, first generation college students and student retention. Results: Academic struggles, difficulty navigating college resources, and lack of a sense of belonging all interfere with the success of first-generation students. Recommendations for nursing faculty to assist these students to be successful are reviewed. Conclusions: Through the use of simple educational strategies, nursing faculty can address the obstacles that hinder first generation students at their institutions, providing them with the tools they need to successful.
\end{abstract}

Key Words: First generation college students, First generation nursing students, Student retention

\section{ANNIE}

Annie was a 20-year-old nursing student who was taking a medical surgical nursing course. Annie was very quiet in class; she did not interact and did not come to any of her professor's open office hours. After failing to meet the required $75 \%$ on an exam, Annie received several electronic warnings with instructions to meet with her advisor, faculty, class teaching assistant, and course tutor. Annie did not follow up with any of the recommendations and only came once to see her professor when asked to specifically make an appointment. During the initial meeting with her professor, Annie offered little insight into the barriers to her success in the course. There was a feeling that perhaps Annie was simply not trying and might not even care. This pattern of disengagement continued until the final exam, which Annie failed-leading her to fail the course. Annie arrived to her professor's office trembling and sobbing to discuss the course failure. Unbeknownst to Annie's professor, this was Annie's second course failure, and she was now considered "out" of the nursing program. Her professor gently asked her why she had never come to office hours. Annie's professor had prided herself on being accessible to the students: with frequent open office-hours weekly, her office was always overflowing with students. Annie looked at her professor through tears and said "I did come, but you were always busy with other students. I stood in the back of the crowd and when you didn't see me I just left." Annie was inconsolable. "Nothing has been easy for me" she exclaimed. "My parents never went to college, they just don't get it. No one understands how hard it is for me." "I'm alone in all this!" The professor's

\footnotetext{
*Correspondence: Margaret Costello; Email: margaret.costello@ simmons.edu; Address: School of Nursing and Health Sciences, Simmons College,
} Boston, United States. 
heart sank when she realized that while she had been convinced that Annie just didn't care, nothing could be further from the truth. Annie wanted to be at college and she wanted to do well. She just didn't know how to achieve success.

\section{THE FIRST GENERATION COLLEGE EXPE- RIENCE}

As a child of parents who were not college graduates, Annie would be classified as a First Generation Student (FGS). A universal definition for what constitutes a FGS does not exist. ${ }^{[1]}$ For example, some admissions offices use the criteria parents who never had any college, other use criteria that include some college. This lack of universal language makes a system for tracking first generation college students very difficult. A common definition is students who do not have a parent who graduated from a 4-year college. ${ }^{[1]}$ FGS arrive at colleges and universities with a unique set of needs. Data from the U.S. Department of Education National Center for Education Statistics revealed that college students who do not have parents with 4-year degrees earn lower grades and encounter more obstacles to success than do students who have at least one parent with a 4-year degree. ${ }^{[2]}$

Researchers have revealed that when compared with students whose parents attended college, first-generation students complete fewer credits, take fewer academic courses, earn lower grades, need more remedial assistance, and are more likely to withdraw from or repeat courses they attempt. First generation students are also less likely to complete a baccalaureate degree than students with parents who attended college. ${ }^{[2]}$ Results of the survey conducted by the Cooperative Institutional Research Program, a survey designed by the Higher Education Research Institute, indicate that students whose parents had college experience were significantly more likely to have higher levels of academic preparedness as identified by higher verbal and math SAT scores. Compared with first-generation students, the odds of scoring above the median on the SAT verbal test were $48 \%$ higher for students with parents both of whom graduated from college and $38 \%$ higher in the mathematics section. ${ }^{[3]}$

College students who interact with professors and peers about their courses are likely to have better outcomes. Yet investigators have shown that FGS have fewer interactions with faculty in the classroom, contribute less frequently to class discussions, and ask fewer questions in class. ${ }^{[4]}$ They have also reported that FGS are less likely to be engaged in the academic and social experience, which can provide structure and academic support. ${ }^{[4]}$ Jenkins, Miyazaki, and Janosik (2009) reported from their research that FGS are less confident of their academic abilities and readiness for college-level work Published by Sciedu Press and are more likely to avoid asking questions or seeking help from faculty. ${ }^{[5]}$ First-generation college students often have difficulty understanding faculty expectations and use of academic vocabulary and jargon in addition to difficulty with time management. These factors further contribute to problems with comprehension and completing assignments. ${ }^{[6]}$ Often first-generation students' underperformance can be linked to a cultural gap that exists between their interdependent norms from their mostly working-class backgrounds that do not match up with middle-class independent norms prevalent in universities. ${ }^{[7]}$

Having a sense of belonging contributes to a student's retention in a college or university. Yet many FGS do not have that sense of belonging. ${ }^{[8]}$ Non-first-generation students report a greater sense of belonging on campus, on average, compared with FGSs. Researchers found that feelings of belonging are significantly related to mental health among students and that first-generation students have a higher frequency of reporting feeling stressed, depressed, or upset compared with non-first-generation students. ${ }^{[8]}$ Researchers have indicated that first-generation students isolate themselves and are less likely to disclose and discuss feelings of stress than their peers. ${ }^{[9]}$ For students who are not as engaged in the college experience, life at college can be isolating. The sense of disconnection can be magnified when students are in large classrooms, which by their nature tend to limit interactions with faculty. Beattie and Thiele (2016) found that large class size negatively influenced FGS' but not other students' likelihood of talking to faculty or teaching assistants about course content. ${ }^{[10]}$ Some have attributed this sense of alienation to the fact that FGS frequently live at home due to financial constraints, that necessitates commuting to school instead of living on campus. ${ }^{[11]}$ Students who commute may find themselves with little time to socialize with other students or participate in learning communities and study groups. ${ }^{[11]}$ Efforts to address the social and educational needs of the commuter student are an important consideration. Interestingly, these researchers also found that even if students live on campus, they are not likely to engage in extracurricular activities, interact with faculty and other students, or use support services. ${ }^{[11]}$

\section{EFFORTS TO SUPPORT FGS}

First generation students have unique needs that represent an opportunity for nursing faculty to provide support to ensure students' success. Many FGS are also minority students. ${ }^{[4]}$ Researchers have found that academic and peer support for minority students before admission and during nursing programs have increased success in minority recruitment, retention, graduation, and achievement on NCLEX. ${ }^{[12]}$ Petty 
(2014) advocated a bridge program from high school to college to help prepare FGS for the college experience. Bridging or pipeline programs have been found to increase retention and graduation success in nursing programs. ${ }^{[13]}$ Academic support and mentoring have been found to be the most valuable services that these bridging programs offer. ${ }^{[12]}$ Since many students from disadvantaged backgrounds arrive at college without the academic preparation necessary to achieve success, exposure to use of the writing and tutoring centers in addition to academics such as tutoring and college preparatory courses can be very useful. ${ }^{[14]}$ Services that could be offered during summer bridge programs could include exposure to available resources and norms and expectations of college life, such as meeting with faculty. ${ }^{[15]}$ Opening these services to families may be helpful to provide parents with a sense of connection to the college and an understanding of their student's experience. Students can benefit from writing intensive courses and first-year seminars and support through the academic achievement office in the form of academic support services, such as tutoring and study skills. Researchers have found that the extent to which students feel that they belong in the academic environment positively affected the degree to which they viewed themselves as capable students. Students with a strong sense of belonging in an institution also see themselves as being capable of greater success in college with a greater sense of supportive self as a successful student. ${ }^{[16]}$ Faculty who serve in an advisor role to students can be positive influences on the students' success. Students who perceive their academic advisors to be very supportive have a stronger sense of belonging and more positive perceptions of themselves as successful students. Faculty can help students have a greater sense of belonging by structuring academic assignments that can promote social learning. Learning communities and service learning opportunities can enhance academic and social engagement. Group activities in the classroom can promote a sense of belonging and attachment toward other students, faculty members. ${ }^{[15]}$ Faculty mentoring can be valuable resource for FGS. Nursing faculty who were also the first in their families to attend college can provide mentorship to first-generation students as well, helping them to navigate their transition to the college or university and serving as a source of encouragement. Researchers have revealed that first-generation college students who are not encouraged by family to attend college may find support from faculty who can become mentors and encourage students. ${ }^{[17]}$ Stuber (2011) found that first-generation students were more engaged in the college experience when involved in a program that targeted their underrepresented group. ${ }^{[18]}$ This study provides validation for the idea that programs aimed supporting FGS should both connect stu- dents to others like themselves in addition to fostering their connection to the campus community as a whole. ${ }^{[18]}$

Students in nursing universally report that nursing education is stressful. ${ }^{[19]}$ Nursing faculty can foster informal faculty student interactions by getting to know FGS and letting them know that they want them to succeed. Early positive student faculty relationships can set a foundation for ongoing academic success. ${ }^{[20]}$ First generation students often suffer from stress silently and feel they are alone in their struggles. ${ }^{\text {[9] }}$ Having an ally can make all the difference. One practice I started since my experience with Annie is to include in my introduction on the first day of class that I am a first generation college graduate from an immigrant family. Since I developed this practice, I have had FGS come to me and disclose that they are first generation. This simple act can break down walls of isolation that can surround the first generation student.

\section{ANNIE EPILOGUE}

Over the course of the following semester, Annie met with both her academic advisor and counselor to help her overcome issues related to anxiety. She was also provided with additional support through the academic achievement office. Annie applied to the Nursing Academic Review Board for reinstatement in the nursing program. She described the challenges she faced as a FGS such as dealing with parents who were always questioning the benefit of a college education in relationship to the high tuition. Annie discussed how she felt inadequate surrounded by students who effortlessly navigated the college scene while she struggled with basic concepts such as what is a "syllabus". Annie benefited greatly from consistent meetings with her academic advisor and counselor. She learned how to address her parents' concerns about the benefit of a college education calmly and in a way they could understand. Her ability to be open to them created greater understanding and in return they were more supportive of her goals. Annie was diligent about seeking out academic support and meeting regularly with faculty. She described the growth she had experienced over the semester both in terms of academics and confidence. Annie articulated her feelings of wanting more than anything to be a nurse, and that she was committed to moving forward utilizing all the resources available to her. The Academic Review Board responded by allowing Annie to return to the nursing program.

\section{Conclusion}

A bridging program is beneficial and can address many of the students' initial academic needs; however, once a student is admitted into a nursing program, efforts must be made to 
support the student toward the goal of success throughout the entire program up to and including graduation. ${ }^{[21]}$ Academic struggles, difficulty navigating college resources, and lack of a sense of belonging all interfere with the success of firstgeneration students. Orientation of all faculty to the special needs of FGS is an important consideration. Strategies that nursing faculty can utilize to support FGS involve providing academic practices that foster a sense of belonging, such as learning communities and group activities. Faculty can seek out those students who are quiet and do not meet with them to let them know of their availability. Faculty can also provide

\section{REFERENCES}

[1] Davis J. The first generation student experience: Implications for campus practice, and strategies for improving persistence and success. Virginia: Stylus Publishing; 2012. 217 p.

[2] Chen X, Carroll C, National Center for Education Statistics (ED) W. First-Generation Students in Postsecondary Education: A Look at Their College Transcripts. Postsecondary Education Descriptive Analysis (US) 2005 Report. NCES 2005-171. 83 p.

[3] Atherton M. Academic Preparedness of First-Generation College Students: Different Perspectives. Journal of College Student Development. 2014 Nov; 55(8): 824-829. http://dx.doi.org/10.13 $53 /$ csd. 2014.0081

[4] Engle J, Tinto V. Pell Institute for the Study of Opportunity in Higher, E. Moving Beyond Access: College Success for Low-Income, FirstGeneration Students. Pell Institute for The Study of Opportunity In Higher Education. (US); 2008 Feb. Report: 38 p.

[5] Jenkins AL, Miyazaki Y, Janosik SM. Predictors that distinguish first generation college students from non-first generation college students. Journal of Multicultural, Gender and Minority Studies. 2009 Dec; 3(1): $9 \mathrm{p}$.

[6] Collier PJ, Morgan DL. "Is that paper really due today?": Differences in first generation and traditional college students' understandings of faculty expectations. Journal of Higher Education. 2008 May; 55: 425-446. http://dx.doi.org/10.1007/s10734-007-9065-5

[7] Stephens NM, Hamedani MG, Destin M. Closing the social-class achievement gap: A difference-education intervention improves firstgeneration students' academic performance and all students' college transition. Psychological Science. 2014 October; 25(4): 943953. PMid:24553359 http://dx.doi.org/10.1177/095679761 3518349

[8] Stebleton MJ, Soria KM, Huesman RL. First-Generation Students' Sense of Belonging, Mental Health, and Use of Counseling Services at Public Research Universities. Journal of College Counseling. 2014 April; 17(1): 6-20. http://dx.doi.org/10.1002/j.2161-188 $2.2014 .00044 . \mathrm{x}$

[9] Barry LM, Hudley C, Kelly M, et al. Differences in self-reported disclosure of college experiences by first-generation college student status. Adolescence. 2009 Spring; 44(173): 55-68. PMid:19435167

[10] Beattie IR, Thiele M. Connecting in Class? College Class Size and Inequality in Academic Social Capital. Journal of Higher Education. 2016 May/Jun; 87(3): 332-362. http://dx.doi.org/10.1353/j he. 2016.0017 multiple ways for students to learn about available academic resources, for example on the course website, provide links, in the syllabus, and verbal reminders and during class time. Faculty who are first generation may disclose their status to so that students will feel that they are not alone. Through these interventions, nursing faculty can address the obstacles that hinder first generation students at their institutions, providing them instead with the confidence and connection they need to succeed.

\section{CONFLiCTS OF INTEREST Disclosure}

The author declares that there is no conflict of interest.
[11] Stcblcton M, Soria K. Breaking down barriers: Academic obstacles of first-generation students at research universities. Learning Assistance Review. 2012 Fall; 17(2): 7-19.

[12] Brooks Carthon JM, Nguyen T, Chittams J, et al. Measuring success: Results from a national survey of recruitment and retention initiatives in the nursing workforce. Nursing Outlook. 2014 July/August; 62 (4): 259-267. PMid:24880900 http://dx.doi.org/10.1016/j.out look. 2014.04.006

[13] Petty T. Motivating first-generation students to academic success and college completion. College Student Journal. 2014 Summer; 48(2): 257-264.

[14] Engle J, Bermeo A, O'Brien C. Pell Institute for the Study of Opportunity in Higher, Education. Straight from the Source: What Works for First-Generation College Students. Pell Institute For The Study of Opportunity In Higher Education. (US); 2006 Feb. Report: 48 p.

[15] Kuh GD, Cruce TM, Shoup R, et al. Unmasking the Effects of Student Engagement on First-Year College Grades and Persistence. Journal of Higher Education. 2008 Sept; 79(5): 540-563. http: //dx.doi.org/10.1353/jhe.0.0019

[16] Curtin N, Stewart AJ, Ostrove JM. Fostering Academic Self-Concept: Advisor Support and Sense of Belonging among International and Domestic Graduate Students. American Educational Research Journal. 2013 Feb; 50(1): 108-137. http://dx.doi .org/10.3102/0 002831212446662

[17] Blackwell E, Pinder PJ. What are the motivational factors of firstgeneration minority college students who overcome their family histories to pursue higher education? College Student Journal. 2014 Spring; 48(1): 45-56.

[18] Stuber JM. Integrated, Marginal, and Resilient: Race, Class, and the Diverse Experiences of White First-Generation College Students. International Journal of Qualitative Studies In Education. 2011 Jan; 24(1): 117-136. http://dx.doi.org/10.1080/0951839100364 1916

[19] Galbraith ND, Brown KE, Clifton E. A Survey of Student Nurses' Attitudes toward Help Seeking for Stress. Nursing Forum. 2014 JulSep; 49(3): 171-81. PMid:24392669 http://dx.doi.org/10.11 11 /nuf . 12066

[20] Soria KM, Stebleton MJ. First-generation students' academic engagement and retention. Teaching In Higher Education. 2012 Dec; 17(6): 673-685. http://dx.doi.org/10.1080/13562517.2012 .666735

[21] Murray TA, Pole DC, Ciarlo EM, et al. A Nursing Workforce Diversity Project: Strategies for Recruitment, Retention, Graduation, and NCLEX-RN. Nursing Education Perspectives. 2016 May/June; 37(3): 138-143. 